\title{
"VEXATIOUS AND AN ABUSE OF THE PROCESS OF THE COURT": THE ASSETS COMPANY V MERE ROIHI CASES
}

\author{
Bryan Gilling*
}

\begin{abstract}
The history of the Assets Co v Mere Roihi decision, a well-known early Privy Council authority on indefeasibility of title under the Torrens system of land registration, illustrates the vulnerability of Maori to irregular land acquisition methods during the late $19^{\text {th }}$ century. It also highlights the inadequacies of the Native Land Court system at the time. The author argues that the policy demands for legal certainty created a hidden and undue cost on the Maori participants: as a result of the case, Maori lost their main opportunity to gain redress for effectively or actually fraudulent dealings in their lands, and for mistakes made by the Land Court.
\end{abstract}

The Privy Council decision in Assets Company v Mere Roihi is a widely known authority for the doctrine of the indefeasibility of title. ${ }^{1}$ The case most famously determined that there can be no going behind a current registered owner in accusations of fraudulent dealings in real estate unless they were directly involved in the alleged dishonesty. Any fraud or similar problem committed further back in the chain of ownership cannot result in the land being returned to the former owner who was defrauded.

Less well known are Assets' immediate implications: that this case concerned Maori land on the East Coast of which Maori owners argued they had been defrauded, and that the additional burden of the costs of litigation was borne by other Maori in Poverty Bay, the shareholders in the Mangatu Incorporation. The Privy Council ruling ended a long battle to have the lands returned; government decisions forced the allocation of costs. Particular Maori lost large amounts of both land and money, but there were much wider ramifications. Maori generally had closed to them their main opportunity to gain redress for fraudulent dealings in their lands and slipshod handling of title investigations in the Native Land Court.

* Senior Research Associate, Treaty of Waitangi Research Unit, Victoria University of Wellington; Consultant, Kensington Swan.

1 Assets Co Ltd v Mere Roihi and Others (1904-05) NZPCC 275; [1905] AC 176; [1904-7] All ER Rep Ext 1599 (PC) Lord Lindley. Also reprinted in [1905] AJHR A 4. 
The history of the litigation illuminates the lengths to which Maori were forced to go - more often than might be expected - to either protect their lands or be dealt with fairly over them. It also indicates the complexity of the judicial and statutory regimes with which they were forced to come to grips. On a broader level, the Assets Company v Mere Roihi litigation provides another cautionary tale about the cost exacted on individuals in the quest for legal certainty, while showing that aspects of the land transfer system now taken for granted took legislators and judges quite some time and effort to work through and resolve.

\section{THE HISTORY}

Court judgments do not occur in a time-space vacuum, devoid of all but legal principle. A long and convoluted series of events led to this judgment and it had an ongoing practical effect. Before analysing the litigation, it is helpful to see its narrative context.

The Assets Co v Mere Roihi judgment was actually a consolidation of six appeals against New Zealand Court of Appeal judgments in three cases, each of which dealt with a pair of Maori complaints about the blocks in question, the title to which was by then held by the Assets Company. ${ }^{2}$ The central issue for Maori was the original purchase of land by Robert Cooper in the Waingaromia Nos 2 and 3 Blocks and the Rangatira No 2 Block in the 1870s. ${ }^{3}$ These blocks had been investigated by Judge John Rogan in the Native Land Court in 1876 and ultimately - despite it being clear that Cooper had even drawn up deeds of conveyance in favour of himself and had lied about having the agreement of all owners as the Native Land Act 1873 required - memorials of ownership were issued. ${ }^{4}$ Subsequent Maori protests included taking legal action against Cooper's ownership and its endorsement by the Native Land Court. Each case had varying facts within the following broad scenario. ${ }^{5}$

Cooper had, through trading firm Kinross \& Graham, rapidly onsold his interests to a Scots firm, Potter, Wilson \& Co, which had immediately collapsed, its assets being acquired by the liquidators of the City of Glasgow Bank. In 1882, the Imperial Parliament passed the City of Glasgow Bank Liquidation Act creating the Assets Company of Edinburgh to manage the failed bank's assets, now including numerous East Coast mortgages from transactions such as Cooper's

2 The cases were: Mere Roihi and Others v Assets Co Ltd and Wi Pere and Others v Assets Co Ltd (1902) 21 NZLR 691; 5 GLR 73; and Panapa Waihopi and Others v Assets Co Ltd and Wiremu Pere and Others v Assets Co Ltd (1902) 22 NZLR 37; 5 GLR 166; and Teira Ranginui and Others v Assets Co Ltd and Heni Tipuna and Others v Assets Co Ltd (1902) 22 NZLR 1.

3 The blocks are in inland northern Poverty Bay. The story is told in more detail, although not entirely accurately, in Kathryn Rose Te Aitanga-a-Mahaki Land (1999-2000) Wai 814 Record of Documents [ROD] \#A17 and \#A18, vol 1, 365-400.

4 The difficulties surrounding these hearings are discussed in Rose, above n 3, vol 1, 83-122; 360-392.

5 William Lee Rees always represented the Maori plaintiffs and Cecil de Lautour almost always represented the Company, facts which became important in several decisions. 
which it had financed. Amidst these transactions, the Native Land Court several times completed or changed Judge Rogan's orders, the Crown purchased some owners' shares, and some of the transactions were entered on the provisional land register.

The New Zealand courts dismissed several actions but upheld several of the claimants' cases, albeit reluctantly, as discussed below. So in order to rid itself of the ongoing litigation, in February 1903 the Assets Company approached the New Zealand government seeking assistance to reach a settlement with the complainants and offering to pay $£ 20,000$ to Maori to clear the blocks' titles. Several technicalities hindered this offer, for which the Company sought legislative clearance. The Solicitor General approved government facilitation of such a settlement, protected by a special statute. However, on 4 May Cabinet ruled out helping to resolve the matter, concluding: "The Gov[ernmen]t does not see its way to interfere in this matter."6

The reason for the refusal is unclear. It may well have flowed from a pre-existing government policy to block Maori challenges threatening titles, some of which are discussed below. The government had already in late 1902 passed the Land Titles Protection Act. Intended to protect titles from "frivolous attack", it responded to challenges to titles as old as Cooper's: challenges which Maori had lost in the Court of Appeal, but which had caused "considerable alarm" to European settlers. It banned the questioning in any court of any Native Land Court order, Crown grant or other instrument issued more than ten years previously unless the action had been commenced prior to 30 June 1902.

In 1905, left with no option by the colonial government's intransigence over resolving a chronic, substantial problem, the Company appealed to the Privy Council, by necessity creating a winnertake-all situation - although presumably, from its earlier settlement offer, not actually expecting to win. The Privy Council overruled the New Zealand courts, awarding all three blocks to the Assets Company, declaring that a current registered owner could not be dispossessed for alleged fraud committed by a former owner. The Maori plaintiffs were ordered to pay some $£ 5,000$ costs incurred by the Company in relation to the several cases.

Maori petitioned, protesting the Privy Council's decision, first because it was delivered by a foreign court which knew nothing, they said, of New Zealand's laws and the intricacies relating to Maori land. They also complained that if the government had intervened as requested in 1903, the case would not have proceeded and they would have been $£ 20,000$ better off, and without the present additional debt. They sought legislation to remedy the injustice thus inflicted on them, initially winning a sympathetic recommendation from the Native Affairs Committee of a full

6 Quoted in Rose, above n 3, vol 1, 392.

7 The costs were allocated thus: Mere Roihi (£1,278 costs), Panapa Waihopi (£892 costs), and Teira Ranginui $(£ 1,566)$. Additional charges such as interest rapidly accrued from 19 February 1906. 
government enquiry and at least an equal redistribution of costs over all Maori "concerned and liable". 8

Probably thanks to Native Minister James Carroll's intervention, the government set aside $£ 5,000$ in the Appropriations Act 1906 for a loan assisting Maori with those legal costs. ${ }^{9}$ This being merely a loan, it was in 1908 then converted into a mortgage on Lots 19 and 20 of Mangatu $1 .^{10}$ This block was some distance away and had only some owners in common with the blocks subject to litigation. The mortgage was repaid when in October 1913 the Mangatu Incorporation, the Maori body which administered Mangatu 1, borrowed £50,000 from the Public Trustee. But since Maori had not repaid the loan quickly enough, or paid instalments on it, the government retrospectively increased the interest rate from $5 \%$ to $6.5 \%$. So on 27 January 1914 , on an advance of $£ 4,831$ six years previously, the Incorporation eventually repaid $£ 6,78214 \mathrm{~s} 4 \mathrm{~d}$, an interest cost of $£ 1,9516 \mathrm{~s}$ 11d. ${ }^{11}$ The Public Trustee only paid the penal $6.5 \%$ "under protest" and pending the Cabinet's decision, but Cabinet overruled him. ${ }^{12}$ These costs were not the only financial outgoings associated with the business, though, and Mangatu Incorporation alone spent in total of $£ 10,492$ on the cases one way or another - a very large sum for the time. ${ }^{13}$

8 Quoted in Rose, above n 3, vol 2, 296: petitions from Heni te Auraki and nine others, Heni Tipuna and 29 others, and committee report: MA 1 07/426. However, when returning to consider the matter fully, the committee had obviously cooled somewhat and made no further recommendation beyond one that the government should note the Privy Council's interpretation of New Zealand law: MA 107/426.

9 The first instalment was $£ 1,566$ paid immediately to the Company to stop a mortgagee sale in the Rangatira Block. A second of $£ 2,245$ was made on 11 February 1907, to stop further sales and extinguish the Company's claim against Mere Roihi and others involved in the Waingaromia actions: JW Nolan to TN Broderick (31 May 1907) Letter. To these were added, though, the bill of $£ 1,020$ from White and Rees as counsel: MA 1 07/426.

10 Nolan and Skeet to Under-Secretary, Native Department (5 May 1908) Letter: MA 1 07/426. The interest was set at this time at $5 \%$ per annum. The mortgage secured $£ 5,000$ but since the mortgagors had received only $£ 4,831$ the lesser sum was the amount on which the Native Department expected them to pay interest. TW Fisher to Nolan and Skeet, 18 June 1908: MA 1 07/426. From the start of the transaction the government had the security of having the judgments assigned to it. Already in January 1907, Carroll had stated that negotiations were under way to sell two blocks to repay the entire liability, but either this sale did not proceed or the two blocks were not the two Mangatu lots: J Carroll undated memorandum: MA 1 07/426. The apparent link between the blocks under dispute and Mangatu 1 was that some of those involved in the court actions were also Aitanga-a-Mahaki owners in Mangatu 1.

11 Rose, above n 3, vol 2, 298. TW Fisher (27 January 1914) Memorandum and Treasury receipt (31 January 1914): MA 1 07/426.

12 Public Trustee to Under-Secretary, Native Department (19 January 1914) Letter: MA 1 07/426. Cabinet confirmed the rate on 27 January 1914: MA $107 / 426$.

13 Brian Murton Te Aitanga-a-Mahaki, 1880-1960: the Economic and Social Experience of a People (2001) Wai 814 ROD \#A26 166. 
Thus the Crown could at a number of stages, but most definitively and obviously in 1903, have averted the harm that befell Maori owners over this series of events. During the development of the situation in the 1880s there was opportunity for intervention, but especially in 1903 when the Assets Company made a seemingly generous settlement offer and only required the Crown to validate the settlement legislatively. Yet the Crown refused to exert itself, at little or no cost to itself. As a result, the Maori owners, whom New Zealand courts had recognised as having been defrauded of their lands, lost both a settlement and the lands, while they and others were saddled with the extensive costs resulting from the cases having travelled through the length of the judicial system.

\section{THE LITIGATION}

\section{A Precedent Cases}

The earliest case on these blocks was Matai v Assets Company, tried by Prendergast CJ in 1887. ${ }^{14}$ The successors to Ema Matai, represented by WL Rees, claimed the transfer from Ema to Robert Cooper was invalid for various reasons. They alleged that the bank liquidators through their agents were parties to the transfer title obtained by Cooper and that through their agents the liquidators also had knowledge of all the facts invalidating the transaction.

Some fifty Maori were found in 1877 by the Native Land Court to be entitled to the block. Cooper had gained a transfer from Ema and others in 1877, while the land was still subject to a proclamation under the Immigration and Public Works Act 1871 banning private purchasers. Cooper mortgaged his interest for $£ 10,000$ to Kinross \& Graham who were acting for Scots firm, Potter, Wilson \& Co. Before a transfer to Potter \& Wilson was registered, the government lodged a caveat due to its own purchasing interests and a rehearing of the block vacated the register. In the meantime, Potter \& Wilson became bankrupt and their assets passed to the Assets Company as outlined above.

Prendergast CJ found that Cooper had in no way acted as the agent of the liquidators, nor had the liquidators' agents been shown to have any actual knowledge of a defect in Cooper's title. Whether or not Cooper had acted fraudulently, subsequent owners had purchased in good faith, and "only with a view to removing doubts and difficulties"; their conduct indicated only a bona fide belief that all requirements protective of Maori had been met, but had not been formally recorded. He concluded that it was "impossible under such circumstances to say that the agents of the liquidators have been guilty of fraud". ${ }^{15}$ This judgment was not appealed.

14 Matai v Assets Co Ltd (1887) 6 NZLR 359 (SC). The block concerned is not named in the judgment.

15 Matai v Assets Co Ltd, above n 14, 363. 
The second case was Peta Toto v Assets Company. Conolly J tried this on 12-13 August 1897, but considering it substantially the same as Matai, he followed that judgment and found for the Company. ${ }^{16}$ This, too, was not appealed.

The third case was Hama Tikitiki v Assets Company, relating to Waingaromia 2, also tried by Conolly $\mathrm{J}$ with the same outcome, but this time unsuccessfully appealed by the plaintiff in October 1899. ${ }^{17}$ The plaintiff's case was that a memorial of ownership made by Judge Rogan on 20 December 1876 was not superseded by a freehold order Rogan made in Cooper's favour on 16 June 1881 but with retrospective effect from 28 June 1877 . The 1881 order was invalid and should not have been registered. A fraud had been committed and thus the Company had no better title than its predecessors on the title. Justice Conolly insisted that so long as the Native Land Court had fulfilled its task of explaining to Maori the full effect of the sale, and was certain they understood, "it must be absolutely immaterial for the purposes aimed at when the transfer is signed". ${ }^{18}$ There was no court roll containing the freehold order, but it was held that the court's administrative failure should not prejudice the purchaser, while to uphold the challenge to the order impeached the Crown grant issued pursuant to it, a prospect the court refused to contemplate. ${ }^{19}$ The Supreme Court did agree that the antevesting in Cooper was done without authority, but considered it valid from 1881 only. ${ }^{20}$

As to the other apparent irregularities, there was no clear evidence of official misfeasance and the court cited a presumption: ${ }^{21}$

upon a well-known principle, that the acts of public officials in the discharge of their duty have been

regularly and properly performed unless the contrary be clearly proved.

This principle was cited in a number of these cases, dealing as they were with the actions of several judges and registrars. Clearly, though, the court was motivated by policy considerations. Having concluded that all elements of a "complete right" existed, and that purchasers had no duty to investigate behind a Native Land Court order, it stated: ${ }^{22}$

16 Unreported but cited in Mere Roihi and Others v Assets Co Ltd; Panapa Waihope and Others v Assets Co Ltd; Teira Ranginui and Others v Assets Co Ltd (1901) 20 NZLR 54, 60 (SC) ["Mere Roihi (1901)"].

17 Hama Tikitiki v Assets Co Ltd and the District Land Registrar, Poverty Bay (1900) 18 NZLR 226 (CA) Edwards J. The other Court of Appeal judges were Williams and Denniston JJ.

Hama Tikitiki v Assets Co Ltd, above n 17, 237.

19 Hama Tikitiki v Assets Co Ltd, above n 17, 239; 240.

20 Hama Tikitiki v Assets Co Ltd, above n 17, 240.

21 Hama Tikitiki v Assets Co Ltd, above n 17, 242.

22 Hama Tikitiki v Assets Co Ltd, above n 17, 244. 
the defendant company is ... entitled to the protection of the Land Transfer Act, even if it should be held that it is not a purchaser for value from a registered proprietor. To hold otherwise would be to throw all titles originally founded upon orders of the Native Land Court into doubt and discredit, and unnecessarily to fritter away the beneficial provisions of the Land Transfer Act.

To that it might be objected that the Land Transfer Act's protections regarding fraud were available only to purchasers for value from a registered proprietor, and that clearly these "irregularities" were intended to be validated by neither the Native Land nor Land Transfer legislation.

A fourth case, Harata $v$ Assets Company, also relating to Waingaromia 2, was heard by Conolly $\mathrm{J}$ in February 1900. On deciding it was substantially identical with the previous three cases, and that they had been brought by the same solicitor - Rees - he thought the result inevitable and thought the proceeding unjustifiable and solely to cause "annoyance and expense" to the Company. ${ }^{23}$

\section{B Any Real Issue?}

There were three cases run together through most of the subsequent litigation on this matter (with three more eventually paired with them). The plaintiffs were Mere Roihi and others, Panapa Waihope and others, and Teira Ranginui and others. Initially they were heard by Justice Conolly in the Supreme Court in Gisborne in April and May 1901, and he delivered his judgment in Auckland on 26 June $1901 .^{24}$

Each action had much in common, and in each of these cases de Lautour for the Assets Company had moved for a dismissal on the grounds that the cases had already been brought by the same solicitor - Rees - and by others of the original owners of the same blocks of land, that the present plaintiffs could have been added to those actions, that they had nevertheless stood by while those claims were tested, that all the preceding actions had been decided in the defendant's favour, and that almost no costs had yet been paid by the unsuccessful plaintiffs in any of them.

Mere Roihi's case referred to Waingaromia 3A and repeated the allegations made in a previous action by Mere Peka Kaimoko. These were that:

- by a Native Land Court order of 27 December 1876 she had been declared an owner;

- $\quad$ she had never sold her interest or authorised another to sell on her behalf;

- the company fraudulently obtained a memorial of ownership and an endorsement by the Chief Judge vesting the land in Robert Cooper;

- the order was not in accordance with law; and

23 Unreported judgment, reproduced in full in Mere Roihi (1901), above n 16, 60.

24 Mere Roihi (1901), above n 23. 
- thereby the company fraudulently obtained a certificate of title under the Land Transfer Act.

Mere Roihi and twelve others now added additional allegations that:

- a conveyance to Cooper, lodged about 27 December 1876, had been signed by the Maori owners before the court order of that date was made;

- Cooper obtained the court order in freehold tenure dated 28 December 1876 although there was no court sitting between 27 December 1876 and 12 April 1877; and

- the plaintiffs never sold their interests or had the transaction examined by a Trust Commissioner. ${ }^{25}$

Mere Peka Kaimoko's case had been tried by Justice Conolly in Gisborne on 14-16 February 1900, the same days during which he heard Harata. ${ }^{26}$ Findings of fact revealed the shambolic state of the Native Land Court's records. The order had been actually drawn up and signed "long after" by Chief Judge Macdonald on (by then retired) Judge Rogan's behalf, when the real date had been forgotten. This was shown with the endorsement on the memorial as it designated Rogan as "retired judge", when he did not retire for five years after the order's date, and the Chief Judge only acquired authority to sign orders for a retired judge in $1881 .^{27}$ Although the memorial of ownership was actually dated 22 March 1876, it purported to represent an inquiry concluded on 31 December 1876, and was not prepared until 1888 .

Unswayed by this clear evidence of institutional failings, Conolly $\mathrm{J}$ had clearly lost patience with hearing Maori land claims in Gisborne. He dealt with all three cases together under the motion for dismissal. Inter alia, he concluded that all of these actions were brought without any expectation of success, but solely to harass the Company, intending to force some settlement, particularly since the present claimants could have joined with the earlier actions. Considering the process a "scandal", he sought to prevent any more actions, dismissing these: ${ }^{28}$

on the ground that all the present plaintiffs could have been added as plaintiffs in former actions if they had chosen so to be, having a common interest, and that these actions are vexatious, and an abuse of the process of the Court.

25 That is, a commissioner appointed under the various Native Lands Frauds Prevention Acts to scrutinise all private sales of Maori land and determine their fairness and correctness.

26 His written judgment, delivered on 18 April 1900, had never been reported, so he reproduced it in full in Mere Roihi (1901), above n 23, 56-58.

27 Native Land Acts Amendment Act 1881.

28 Mere Roihi (1901), above n 23, 66. 
The full bench of the Court of Appeal, however, disagreed unanimously, demonstrating conclusively that indefeasibility of registered title was still then a live issue. ${ }^{29}$ Having heard only de Lautour for the defendant Company, they allowed the plaintiffs' appeal. Stout CJ was unconvinced that Matai was conclusive authority in this case at all. ${ }^{30}$ Whether the irregularities were such as to permit the title to be challenged was a "difficult question of law", he said, and should be argued properly, rather than in this fashion. Also, Conolly's contention that present plaintiffs should have joined similar actions was simply wrong. The owners were tenants in common with separate rights and therefore entitled to test this important point of law, which "yet remains to be decided", through to the Privy Council, if they wished. ${ }^{31}$

Denniston J agreed, adding: ${ }^{32}$

It comes to this, therefore: that it is argued that the plaintiffs were improperly excluded from a hearing in the previous actions, and yet that they cannot be heard now in the actions which they have themselves brought...

Until the question was decided by the Privy Council, no-one not a party to the former cases could be prevented from bringing their own action, while an action could only be dismissed as frivolous where a line of old cases had already settled the law beyond doubt.

Edwards $J$ called any claim of a "community of interest" amongst the plaintiffs "clearly erroneous", while the Company itself had previously objected to the actions being treated as representative. He also was certain that both Matai and Hami Tikitiki were "clearly distinguishable". The appellants, therefore: ${ }^{33}$

have a substantial question which they are entitled to have litigated in the Supreme Court, in this Court, and, if necessary, in the Privy Council.

29 Mere Roihi and Others $v$ Assets Co Ltd (1902) 21 NZLR 449 (CA) ["Mere Roihi (1902) A"].

30 It had been decided two years before the memorial now challenged was issued, while the Company took over with full knowledge that there was no memorial of ownership and that therefore there was no Native Land Court declaration that the persons executing the conveyance were entitled.

31 Mere Roihi (1902) A, above n 29, 459. Williams J said that the factual allegations remained to be substantially determined, yet a motion to dismiss must show that "the claim is so bad in law that it is impossible under any circumstances that the plaintiffs could recover".

32 Mere Roihi (1902) A, above n 29, 460.

33 Mere Roihi (1902) A, above n 29, 463. 
That decision was handed down on 20 March 1902. ${ }^{34}$ The trial of the Mere Roihi and Wi Pere cases came on before Edwards J in Gisborne on 26 April, but in early May he removed them to the Court of Appeal for argument and judgment.

Before the substantive hearing began, for the Company, H.D. Bell now argued that the matter should not proceed until all persons who would be entitled were joined as either plaintiffs or defendants, that: ${ }^{35}$

The plaintiffs have none of the qualities of tenants in common. Under a memorial of ownership no less than the whole of the owners could convey. The memorandum of transfer and the order of freehold tenure must therefore be either good or bad as a whole. Even if the Natives were tenants in common they must either all bring one joint action or each a separate action. ${ }^{36}$

In this preliminary hearing, Williams, Denniston and Edwards JJ unanimously rejected the Company's application for postponement, indicating that the plaintiffs had been pursuing this action for some time, the writ was issued fifteen months previously, and that it would be unjust to again postpone their hearing, and for an indefinite period. Denniston J said this could not be done for the defendant's sole benefit, "because of a contingency which may never arise, and which the Court has ample power to meet should it arise". ${ }^{37}$

\section{The Court of Appeal}

The Court of Appeal heard Mere Roihi and Wi Pere on Waingaromia 3 together. The court was divided, two judges finding for the claimants, but with great reluctance, and one dissenting.

Denniston J was driven by his own reasoning to allow the appeal, but expressed "regret" at having done so, because of the Company's good faith and outlay thus far. He thought that Judge Rogan would have "believed that the transaction between Cooper and the Natives, though undoubtedly irregular, was at least as honest as such transactions at that time usually were...."38 Nevertheless, he accepted Edwards J's arguments, concluding the freehold order was "not only irregular but an absolute nullity and void". Thus, no warrant could have been granted upon it nor

34 So said Company counsel at the next hearing, but the NZLR reported the hearing's dates as 21, 24 and 25 March.

35 Mere Roihi (1902) A, above n 29, 463.

36 Mere Roihi and Others $v$ Assets Co Ltd and Wi Pere and Another v Assets Co Ltd (1902) 21 NZLR 673, 674 (CA) ["Mere Roihi (1902) B"]. Plaintiff counsel Rees responded that there was no precedent for plaintiffs to be joined simply so that they might be bound as against the defendant.

37 Mere Roihi (1902) A, above n 29, 683.

38 Mere Roihi (1902) B, above n 36, 728-29. 
certificate of title issued. ${ }^{39} \mathrm{He}$ also distinguished between the provisional and permanent registers, such that:

Purchasers, though for value, from persons on the Provisional Register take with notice of the possible infirmity of their vendor's title. ${ }^{40}$

This was important as he noted that although the Company were purchasers for value from Cooper while he was on the provisional register, they gave no value or consideration at or after the transfer to the actual register. So they were unprotected by the Land Transfer Act and had no better title than did Cooper, and his was non-existent: ${ }^{41}$

The order was an absolute nullity. The foundation for the order in freehold tenure, a memorial of ownership in favour of the Native vendors, on which the various steps necessary to extinguish the Native title ... should have been indorsed, did not exist. The Native title had not in fact been extinguished.

The court roll did not exist, the Chief Judge had made no inquiry, and the Company's solicitors knew the facts yet made an ex parte application to validate a till then invalid and illegal transaction, to make customary Maori land into freehold with an indefeasible title. Denniston concluded: "I cannot but believe that in the eyes of equity the Native owners have been - if these transactions stood - by these proceedings deprived of their land by fraud within the meaning of section 56 of the [Land Transfer] Act." 42

Williams $\mathbf{J}$ dissenting would have disallowed the Maori claim and was "glad to arrive at this conclusion". He felt sympathy for the Company, which was a bona fide purchaser who had already been put to great trouble and expense, while the Maori had only recently made a claim, after virtually everyone involved in the original transaction was dead. He thought that everyone from Kinross \& Graham on had been unaware of a defect in Cooper's title and were all therefore bona fide purchasers for value. ${ }^{43}$ The subsequent steps to "make good their title" had not been fraudulent and he followed Matai's argument and conclusions. He simply did not believe evidence given that the payments had not been made, nor that any such group would have stood quietly by without complaint for so long unless they had been paid. ${ }^{44}$

\footnotetext{
39 Mere Roihi (1902) B, above n 36, 723

40 Mere Roihi (1902) B, above n 36, 725.

41 Mere Roihi (1902) B, above n 36, 726.

42 Mere Roihi (1902) B, above n 36, 728.

43 Mere Roihi (1902) B, above n 36, 717.

44 Mere Roihi (1902) B, above n 36, 722.
} 
Justice Edwards carried the day, writing a lengthy and detailed critique of the Companys' position. He began by noting that the Maori occupation right was guaranteed by the Treaty, then compared the Native Land Court activities centring on Rogan's 1876 hearing with the legislation. His first observation was that the Native Land Act 1873 made the existence of an approved map a condition precedent to the court's power to begin a title investigation. Such a map had never been prepared for Waingaromia 3, so: ${ }^{45}$

It follows that the whole of the subsequent proceedings before the Native Land Court relating to this land were coram non judice, and were void.

He then found that without the map and a proper memorial of ownership, there could have been no valid order in freehold tenure. There was no roll without a memorial, so: ${ }^{46}$

There could therefore be no record; and the whole scheme of the statute is that those claiming under it hold by record of the Court alone.

Cooper's purported memorandum of transfer did not meet a single statutory requirement, therefore there was no transfer put before the court as the basis for the freehold order made in Cooper's favour. ${ }^{47}$ It was already well decided that a valid memorandum of transfer was essential to the Native Land Court's jurisdiction to make a freehold order and that if it acted without a transfer the Native Land Court was exceeding its jurisdiction. ${ }^{48}$

Edwards J declined to rule on the plaintiffs' allegation that the Native Land Court did not itself comply with statutory requirements, such that "the so-called order of freehold tenure was neither a judicial act nor the record of a judicial act". He concurred in the principle from Hama Tikitiki that court records must be treated as being regular unless proved otherwise. However, since the judge had been acting without jurisdiction, had disregarded "in every particular the very plain and explicit conditions" laid down in statute, and had disregarded the statutory protections for women and children, then the presumption that he had complied with the law "becomes so much weakened as almost entirely to be dispelled". ${ }^{49}$ He concluded: ${ }^{50}$

45 Mere Roihi (1902) B, above n 36, 733.

46 Mere Roihi (1902) B, above n 36, 735.

47 Mere Roihi (1902) B, above n 36, 738.

48 Mere Roihi (1902) B, above n 36, 739. Edwards J cited as authority Poaka v Ward (1890) 8 NZLR 338, Rutu Peehi v Davy (1891) 9 NZLR 134 and Re the Okirae Block (1892) 10 NZLR 677.

49 Mere Roihi (1902) B, above n 36, 739-741 Edwards J. He conceded that Rogan was a good Maori linguist and made some sort of inquiry, but being a layman he was "quite unable to appreciate the duties cast upon him by his office", and thus also unable to conduct a proper judicial inquiry as statutorily required. Edwards also commented that since the Native Land Court's records had been kept with "shameful negligence" one could not prove that no inquiry was made or explanation given by Rogan, although it could be shown that Rogan was not even present on the stated day. 
If, therefore, the defendants' title rests upon the order in freehold tenure made by Mr Rogan in favour of

Cooper, it must, in my opinion, fail.

However, there were the additional proceedings of Chief Judge Macdonald. The Company induced the Chief Judge to sign an order purporting to comply with the 1873 Act, but it was not founded on fresh proceedings, so again the Company's claim was still based wholly on proceedings which were coram non judice and thus null and void.

The provisional registration was of less effect than full registration: "it is plain that no one can set up registration upon the Provisional Register as an answer to the claim of the rightful proprietor". ${ }^{51}$ Edwards also dismissed the notion - and its counsel also disclaimed - that the Company was a bona fide purchaser for value: "The defendants purchased nothing and paid for nothing after the land was placed upon the Register." 52

This left the Company to rely entirely upon its status as registered proprietor without fraud. Edwards, though, tracked the various facts and found that the Company, knowing all the prior facts about Cooper's dealings, nevertheless "procured Chief Judge Macdonald to sign a series of documents". These appeared to show Cooper had a complete title, but were actually null and void, yet led to the Governor issuing the warrant for the certificate. Edwards found that these acts constituted fraud within the meaning of the Land Transfer Act. ${ }^{53} \mathrm{He}$ did not find that the Company's agents had been personally dishonest, but it was sufficient if the instrument relied on was itself fraudulent, so the Company's title was affected by actual fraud in its procurement. ${ }^{54}$ Cooper clearly knew of his own fraud and the Company was affected by this. ${ }^{55}$ Justice Edwards continued on in detail arguing that the Governor's warrant, gained by deceit, was therefore void, and said that Gibbs $v$ Messer applied doubly since the Company did not purchase from a registered proprietor and it

50 Mere Roihi (1902) B, above n 36, 741.

51 Mere Roihi (1902) B, above n 36, 747.

52 Mere Roihi (1902) B, above n 36, 747. Its transactions were prior to the provisional register being closed and the Act precluded this from being sufficient.

53 Mere Roihi (1902) B, above n 36, 750.

54 Mere Roihi (1902) B, above n 36, 751, citing Ex parte Davy (1888) 6 NZLR 760, 765.

55 "In order to procure themselves to be registered as proprietors under the Land Transfer Act, they were compelled to adopt the void order of freehold tenure which Cooper had fraudulently procured to be made. They cannot adopt a fraudulent transaction and still rely on it as if it were innocent": Mere Roihi (1902) B, above $\mathrm{n} 36,752$ 
knew the land could be acquired only through very special provisions. ${ }^{56} \mathrm{He}$ was therefore of the opinion that the Company had committed constructive fraud.

\section{The Privy Council}

As we have seen, the Assets Company was prepared to settle at this point and made its offer, but failed to receive the protection it sought from the government. The Company appealed to the Privy Council.

Before the Privy Council, the Maori claim was once again argued on two grounds: the company's registration was fraudulent; and the registration was invalid due to the irregularity of the Native Land Court proceedings and orders.

Lord Lindley gave the judgment for the Board, which was a strict enforcement of the allconquering power of registration. ${ }^{57}$ They refused to distinguish between the first registered owner and any other and upheld Williams J's arguments about registration improving title. ${ }^{58}$ They would not allow that a Crown grant or warrant could be impeached at all, except perhaps by the Crown. Those whose duty it was to act on orders were under no obligation to investigate apparently correct orders, but rather to act on them, and if what they did under them was conclusive as to title, then an otherwise impeachable title must be treated as valid. ${ }^{59}$ They agreed that the memoranda of transfer were invalid, but against Edwards J's argument held that they were the first step for obtaining such transfers and entitled the Company to take the necessary steps to complete them. ${ }^{60}$

Their Lordships summarily dismissed the claim that the registration was obtained by fraud saying bluntly: ${ }^{61}$

The evidence of fraud by the company entirely breaks down. The evidence shows that in all these cases the agents of the Assets Co in the Colony took to the Registrar and got him to register certain documents which, according to their purport and effect, entitled, and which they believed did in fact entitle, the company to be registered as owners. There is no evidence whatever of any fraudulent statement made by the company's agents to the Registrar nor of any bribery, corruption, or dishonesty in the matter.

56 Gibbs $v$ Messer [1891] AC 248 (PC). This case centred on a forged transfer. Edwards J was presumably referring to one ratio derivable from it that registration of a void instrument does not confer an indefeasible title on the newly registered proprietor.

57 Assets Co Ltd v Mere Roihi, above n 1.

58 "A registered bona fide purchaser from a registered owner whose title might be impeached for fraud has a better title than his vendor, even if the title of the latter could be impeached by the Crown": Assets Co Ltd v Mere Roihi, above n 1, 290.

59 Assets Co Ltd v Mere Roihi, above n 1, 291.

60 Assets Co Ltd v Mere Roihi, above n 1, 297.

61 Assets Co Ltd v Mere Roihi, above n 1, 299. 
The nature of fraud was directly dealt with also. Constructive or equitable fraud would not suffice: ${ }^{62}$

by fraud in these Acts is meant actual fraud - i.e. dishonesty of some sort - not what is called constructive or equitable fraud.... Further, it appears to their Lordships that the fraud which must be proved in order to invalidate the title of a registered purchaser for value ... must be brought home to the person whose registered title is impeached or to his agents.... A person who presents for registration a document which is forged or has been fraudulently or improperly obtained is not guilty of fraud if he honestly believes it to be a genuine document which can be properly acted upon.

Their Lordships chastised the Court of Appeal as too soft-hearted in this regard, saying that they "cannot help thinking that the equitable doctrines of constructive fraud have weighed too much with the Court of Appeal and have caused it to impute fraud to the Assets Co, although no dishonesty by the company or its agents, or by the liquidators ... was really established". 63 To reinforce the point, they ignored much of the Company's defence, but concluded: "Their Lordships base their judgment on the conclusiveness of the registered title in the absence of fraud." 64

In their concluding remarks they revealed the policy considerations which also informed their reasoning, particularly that if the registration principles were lost sight of the system would become unworkable. Also, it was necessary to balance against protection of Maori the importance of not disturbing the registered title of bona fide purchasers, "especially when accompanied by long possession and large outlays". 65 They found it "satisfactory" that their conclusions upheld what they saw as the general position taken in New Zealand for "many years".

\section{THE LAW}

At the core of these cases was the formation of the young Torrens land registration system and the legislation implementing it, aiming to give certainty to land titles and efficiency in the conveyancing. As Edwards $\mathrm{J}$ explained in Fels $v$ Knowles immediately after the Mere Roihi decision, it was: 66

a complete system which any intelligent man could understand, and which could be carried into effect in practice without the intervention of persons skilled in the law.... The cardinal principle of the statute is that the register is everything, and that, except in cases of actual fraud on the part of the person dealing

62 Assets Co Ltd v Mere Roihi, above n 1, 298.

63 Assets Co Ltd v Mere Roihi, above n 1, 299.

64 Assets Co Ltd v Mere Roihi, above n 1, 300.

65 Assets Co Ltd v Mere Roihi, above n 1, 298.

66 Fels v Knowles (1906) 26 NZLR 604, 619. 
with the registered proprietor, such person upon registration of the title ... has an indefeasible title against the world.

However, the fact that the Assets judgment concertinas more than one case leads to complications in understanding its exact import. Lord Wilberforce explained the confusion in Frazer $v$ Walker (1967): ${ }^{67}$

The facts involved in each of the appeals were complicated and not identical one with another, a circumstance which has given rise to some difference of opinion as to the precise ratio decidendi - the main relevant difference being whether the decision established the indefeasibility of title of a registered proprietor who acquired his interest under a void instrument, or whether it is only a bona fide purchaser from such a proprietor whose title is indefeasible.

These questions led to a protracted debate between 1905 and 1967 as to whether the first (immediate indefeasibility) or the second (deferred indefeasibility) was intended. In Boyd v Mayor of Wellington, ${ }^{68}$ a majority in the Court of Appeal decided for immediacy and in 1967 this interpretation was confirmed by the Privy Council in Frazer $v$ Walker. Its explanation that the fraud committed must have been actual, not constructive, has been regarded as determinative ever since.

Assets had immediate legal ramifications in New Zealand. In June 1905 Edwards J heard Beale $v$ Tihema te Hau in the Supreme Court, a case in which the plaintiff had bought a block at Waiohau several transactions after the original purchase from Maori, and now sought the ejection of those Maori from their homes, cultivations and villages on the block. ${ }^{69}$ The Native Land Court's investigation of the 7000-acre Waiohau 1 Block in 1878 and its award to only two of the 150 original owners, led to the block's immediate sale to a Pakeha who then promptly onsold it. ${ }^{70}$ Justice Edwards noted that the various problems with the Native Land Court's investigation meant its award was made without jurisdiction and that it could have been overthrown by certiorari. He implied that

67 Frazer v Walker [1967] NZLR 1069 (PC). The problem is over whether the Privy Council decided Assets Co Ltd v Mere Roihi on the basis that "in all three cases the company was a registered bona fide purchaser for value of an improperly registered title or whether in one of the appeals [Teira Ranginui] it was considered that the first entry in the register had been made on the application of the company itself in reliance on invalid documents. If the former, then Assets ... is no authority in favour of immediate indefeasibility. If the latter ... then the Privy Council accepted the doctrine of immediate indefeasibility": GW Hinde and others Land Law in New Zealand (2 ed, LexisNexis, Wellington, 2003) 361.

Boyd v Bishop of Wellington [1924] NZLR 1174.

69 Beale v Tihema te Hau and Others and the Attorney-General (1905) 24 NZLR 883. Boast states that Edwards $\mathrm{J}$ reached his decision in Beale using New Zealand case law without having seen the Assets judgment: Richard Boast "Maori Land and Other Statutes" in Richard Boast and others Maori Land Law (2 ed, LexisNexis, Wellington, 2004) 255. But although the judge did not mention Assets in his decision, the full report reveals that Mrs Beale's counsel did refer to it in his successful submission: 889 .

70 See Boast, above n 68, 255; Judith Binney Encircled Lands (2002) Wai 894 (ROD \#A15) 46-67; 326-351. 
the opportunity for that remedy had now passed, probably because the block was now several registered proprietors within the recent land registration system. He explicitly relied on two 1899 New Zealand cases to assert that a bona fide purchaser for value from other bona fide purchasers for value obtains an indefeasible title although the vendor's certificate of title was issued without authority of law and would be cancelled by a proper proceeding. ${ }^{71}$ It is unclear why he found those so persuasive although he had not a couple of years earlier in the Mere Roihi case, when he had thought earlier fraudulent dealings had similarly meant the Native Land Court operated without jurisdiction and this undermined all subsequent transaction and titles. The effect may well be due to the arrival of Assets and its explicit restrictions to actual fraud by the current registered owner. ${ }^{72}$ Justice Edwards made clear that the plaintiff's evidence was redolent of fraud, but it had not been proved that Mrs Beale herself committed actual dishonesty, and it was with extreme reluctance that he reached the result to which the law now drove him. ${ }^{73}$

Assets has additional legal implications. The case is significant in setting out, albeit implicitly, the principle that fraud by an agent will upset the registered title of the principal. ${ }^{74}$ Apart from the question of fraud, Assets is also authority regarding the effect of provisional registration. It upheld the arguments of Williams $J$ as to permanently registered certificates being conclusive evidence of title, although a title registered only on the provisional register is still subject to the infirmities of the first registered proprietor's title. ${ }^{75}$ It also upheld the integrity of a Crown grant, regardless of

71 Beale v Tihema te Hau, above n 68, 891. The cases were Public Trustee v Registrar-General of Land (1899) 17 NZLR 557 and Solicitor-General v Mere Tini (1899) 17 NZLR 773.

72 Despite the Judge's statement that Mrs Beale was "blameless" it was nevertheless clear to him that she knew that the Maori were still living on the land as they had always done, and that she knew her vendor had never taken actual possession. Also her husband's law firm had acted for all the purchasers through the block's history, as they did for her; there was clearly inside knowledge present of all that had gone on, while Mrs Beale was probably simply a front person for her husband's business dealings. In more recent times the court would have the power to regard the Beales' actions, and those of the prior owners, as registration with the deliberate aim of defeating the equitable interests of the Maori owners, raising the possibility of considering it as fraud under the fraud exception in the Land Transfer Act ss 62-63.

73 He stated that the initial purchaser's own evidence had "conclusively established the fraud". Maori had also been let down at several points by carelessness or negligence on the part of the original Native Land Court Judge and then the Chief Judge when rehearings were applied for, despite that court being "the very Court which was specially charged with the duty of protecting them in such matters". In all, he believed that the defendants had plainly suffered "a grievous wrong". He expressed personal regret at the hardship the judgment caused to them: Beale v Tihema te Hau, above n 68, 888-891.

74 Lord Lindley stated: "The fraud which must be proved in order to invalidate the title of a registered purchaser for value ... must be brought home to the person whose registered title is impeached or to his agents. Fraud by persons from whom he claims does not affect him unless knowledge of it is brought home to him or his agents": Assets Co Ltd v Mere Roihi, above n 1, 298

75 Assets Co Ltd v Mere Roihi, above n 1, 290. 
whether that grant contained errors. ${ }^{76}$ Several less prominent issues were also noted in passing, such as the inability of a Registrar to correct errors in a Crown grant to the detriment of a registered bona fide purchaser. ${ }^{77}$ Nor could a registered proprietor be held to be a trustee for another person who would merely have had a better title apart from the Land Transfer Act. ${ }^{78}$

As Boast observes: ${ }^{79}$

By [the Privy Council's] insisting that "fraud" as used in the Land Transfer Acts meant actual dishonesty, Maori were unable to attack the title of a registered proprietor on the grounds of noncompliance with the Native Lands Acts; by limiting the fraud exception to frauds of the registered proprietor the Judicial Committee facilitated the defeat of Maori claims by the simple method of transfer or mortgage to a third party. Maori were left only with their in personam rights and claims against the compensation fund....

The Assets case is therefore a major landmark in the dispossessing of Maori from their lands, blocking their access to legal redress for recovery of lands from which they been inequitably parted and providing a screen behind which many shady dealings were sheltered from being brought into the light of public and judicial scrutiny. They were swept up in the Torrens system which, when there is a permanently registered bona fide proprietor, deprives of their land other people who had a better title at common law, leaving compensation available, at best.

The point for Maori particularly is that activities like Cooper's were not isolated aberrations as the Torrens system and the doctrine of indefeasibility assume - and indeed must assume if they are to remain intact. In the later nineteenth century all manner of speculators worked to make money from buying Maori land cheaply and selling high and an Assets-type decision made it easy for the fruits of their sharp and often illegal practices to go relatively unpunished, or at least for Maori to be unable to recover their lost land. Similarly, as Edwards J pointed out, the nineteenth-century Native Land Court was technically hardly an institution which could be thoroughly relied on to provide the firm foundation a system of indefeasible titles required. Maori were vulnerable both from the way in which Pakeha were acquiring land, and from the inadequacies of the Native Land Court system.

The harsh effects for Maori landowners of the Assets case are discussed by Boast. ${ }^{80} \mathrm{He}$ summarises the alleged frauds and illegalities perpetrated when the lands were purchased from

76 Lord Lindley stated: "Their Lordships are not prepared to hold that a Crown grant, or a Warrant, or a certificate of title having the statutory effect of a Crown grant, can be impeached except at the instance of the Crown, or at any rate in an action to which the Crown is a party": Assets Co Ltd v Mere Roihi, above n 1, 291. The issue of the Crown's power to set aside its own grant was not in issue here and so no comment was made on it.

77 Assets Co Ltd v Mere Roihi, above n 1, 283.

78 Assets Co Ltd v Mere Roihi, above n 1, 293.

79 Boast, above n 68, 256-257. 
Maori and the failure of the Native Land Court to acknowledge and deal with them. The extent of the fraudulent and potentially fraudulent dealings in Maori land in the late nineteenth century is revealed in the difficulties the Native Land Court had with many of the transactions brought before it, in the number of petitions and other complaints various Maori around the North Island submitted to Parliament through the era, and most particularly in the court judgments and commissions of inquiry that culminated in the creation of the Validation Court. The evidence given in Assets provides a sharply focused exemplar of many of these problems.

As noted at the outset, this case adds to the countless examples of an undue cost exacted on specific individuals as policy imperatives demand legal certainty in some field. It also, more specifically, shows how the creation of a rule intended to deal with rare and isolated incidents titles acquired by fraud being accepted onto the register - acted against a whole class of claimants: Maori seeking to correct past injustices that occurred when the settled land transfer system which the Privy Council envisaged, and which we now enjoy, simply did not exist on New Zealand's colonial frontier.

80 Boast, above n 68, 255-257. 
